\title{
Unintended Consequences Of Equal Employment Opportunity: Unequal Parties In The Selection Process?
}

John N. Orife, Indiana University of Pennsylvania, USA

Maali H. Ashamalla, Indiana University of Pennsylvania, USA

Frederick J. Slack, Indiana University of Pennsylvania, USA

\begin{abstract}
There are various regulations that are intended to promote equal employment opportunity and avoid illegal discrimination in the employment process. These regulations determine what information employers may seek, and require that information sought be job-related or it is illegal to seek such information as age, marital status, or religion. Information that is not a bona fide occupational qualification (BFOQ) is usually out of bounds as employers gather information to determine the suitability of applicants for employment.
\end{abstract}

Since one of the bedrock laws affecting the employment relationship is the "at will" doctrine that assumes both employer and applicant come together as equal partners in the formation of the employment contract, this paper raises the issues about whether such regulations unintentionally leave the employer at an information disadvantage by negating the concept of equality assumed by the "at will" doctrine. Some suggestions for practical ways of reducing the identified employer information disadvantages are provided.

Keywords: Equality In Employment Regulations; Equal Employment Opportunity; Illegal Discrimination In Employment

\section{INTRODUCTION}

ccording to the at-will doctrine in employment, both parties come together of their own free will to form an employment contract. Either party can terminate the contract without the need to find fault with the other party; hence, the notion that under the at-will employment doctrine, an employer may legally terminate an employee for a good reason, a bad reason, or no reason at all. Similarly, an employee may resign (terminate the employment relationship) without the need to provide any justification if there is no contract for a definite term of employment (Phillips and Gully, 2009, p.56). This scenario paints a picture of equality of both parties that have come together to form the employment relationship.

The purpose of this paper is to question the notion that both parties are indeed equal in the process of forming this employment relationship. The approach of the paper is to review the employment formation process in order to isolate any inequalities in the process and to suggest ways of correcting such perceived inequalities.

\section{THE EMPLOYMENT FORMATION PROCESS}

The employer and candidates for employment usually seek each other in the mutual satisfaction of their goals as implied in the recruitment process, which precedes selection and forming of the employment relationship (Phillips and Gully, 2009, p.180). The employer needs certain activities to be performed and the applicant needs certain needs to be satisfied through such employment. The person/job match model clearly illustrates this position (Heneman, Judge, and Kammeyer-Mueller, 2012, p.16). According to the model, the job has certain requirements 
and certain rewards; in order to be considered suitable for the job, an individual must have the necessary qualifications to perform the required duties. In return, the individual receives the rewards provided by the job. There has to be a simultaneous match of requirements and qualifications, as well as the needs or motivation of the individual and the rewards provided by the job. The view that applicants do seek to satisfy their needs when they agree to form an employment relationship is also supported by Rynes and Barber (1990). Since applicants and employers have some control over the formation of the employment relationship, there would be a good case of equality at the contract formation level.

Similarly, the person-organization match model (Heneman, Judge, and Kammeyer-Mueller, 2012, p.18) requires a fit between the organization and the candidate. In this expanded model, there should be a fit between what the individual brings to the table to match the different opportunities provided by the employer. This model expands the opportunities the employer provides beyond the immediate position for which the applicant has applied. The employer, in this model, has provided the applicant more information than the current position requirements and elaborated on the context in which the job of interest exists, such as the culture and future jobs. The question is, "does the employer have a similar context about the candidate's skills set or motivations?"

The employers have to collect data from candidates to determine their suitability for employment before making the offer of employment. What data can the employer legally require candidates to provide? The question will be addressed in the next section which reviews the environment governing the collection of such data by an employer.

\section{THE CONTEXT OF DATA COLLECTION BY EMPLOYERS}

The data collection by employers, relevant to the determination of an applicant's suitability for employment, is governed by various laws and regulations in many Western countries. In the United States and the European Union (EU), various laws and regulations aimed at ensuring equal employment opportunity (EEO) determine what types of questions an employer may ask the applicant for employment in the process of collecting data to determine his or her suitability for employment. These laws and regulations ${ }^{1}$ are supposed to level the playing field so that applicants are judged on the basis of what they can do and not on the basis of their group membership.

In terms of the person/job match model, the process of determining an applicant's suitability for the job should focus on whether the applicant has the necessary skills set to perform the job's duties. Employers, therefore, have to be careful to collect data about factors that make for success or failure on the job (job-related factors) since the theme of the regulations is "Employment decisions should not be based on characteristics such as race, sex, age or disability." (Gomez-Mejia, Balkin, and Cardy, 2001, p.94) The laws require employers to make an unbiased assessment and interpretation of applicants' job qualifications (Phillips and Gully, 2012 p.61). Thus, personal demographics, such as marital status, are off limits because job-relatedness may be difficult or impossible to establish and it tends to have an unfavorable disparate impact on women. "The goal of EEO legislation and regulation [is to have] a situation in which employment decisions are not affected by illegal discrimination." (Gomez-Mejia, Balkin, and Cardy, 2001, p.92) It is, therefore, not advisable to ask an applicant whether he or she is married and, in the case of women, the general belief is that the question may go beyond just knowing the marital status, like when she is likely to have a baby and how that will affect attendance and sick days. These are issues that do not usually arise in the case of men. In terms of EEO or illegal discrimination, this scenario results in disparate effect discrimination. The same standard applies to men and women; that is, asking about their marital status may have a different effect on men and women, with the women getting a potentially unfavorable impact (Gomez-Mejia, Balkin, and Cardy, 2010, p.113). This situation is covered under several laws - the European Union (EU) Equal Treatment in Employment and Occupation Directive (2000/76/EC), law that protects personal data (Sesen, 2006, pp.4-5), as well as the EU Charter of Fundamental Rights since 2009 - Treaty of Lisbon (Basim, Sesen, and Sesen,

\footnotetext{
1 The Civil Rights Act, 1991, and Uniform Guidelines on Employee Selection Procedures in the United States and in the EU, the EU Charter of Fundamental Rights as contained in the Treaty of Lisbon (2009); Article 8 provides for the protection of personal data as a fundamental individual employment right.
} 
2007, p.3); and the 1964 Civil Rights Act and its 1991 revision, as well as the 1978 Uniform Guidelines on Employee Selection Procedures in the United States (Gatewood, Field, and Barrick, 2008, pp.32-33, 50-53). So, employers are not to ask job applicants questions about marital status.

In the case of expatriate selection, however, family considerations are important to the success of the expatriate. Indeed, it has been suggested that "expatriate selection criteria should include ... family flexibility..." (Pace, 2009, p.18). According to Schwartz, President and CEO of GMAC Global Relocation Services, "it is becoming increasingly clear to corporations that when candidates are selected for expatriate assignments, spouses, partners and entire families also need to be 'selected"' (Minton-Eversole, 2009, p.73). It is therefore recognized that in that situation, when the candidate is competing for the job, he or she may be an agent of the family, and it is possible that the candidate is not the final decision-maker in the contract formation process; yet it is illegal to ask the candidate for information about the family.

In these situations, it may be argued that the employer is at an information disadvantage because the employer is not supposed to ask for information about an applicant's family composition - information which is well known to the applicant but not shared with the prospective employer - even though such information may be relevant to success or failure on the job (job-relatedness).

Employers do not similarly collect religious affiliation data because that would tend to have an unfavorable effect on religious minorities. In order not to become liable for charges of illegal discrimination on the basis of religion, we do not ask an applicant about his or her availability for work on the weekend in the United States. Asking for information about weekend availability for work is supposed to be capable of having an exclusionary effect on some people's religious practices (Gomez-Mejia, Balkin, and Cardy, 2010, p.113.). The fact that some businesses operate on a seven-day week does not appear to sway the legal position. In this situation, employers are advised to post the work days of the vacant job so they do not have to ask the applicant about availability for weekend work; so, we usually see that some job advertisements would include such statements as "weekend work required" or "some travel is necessary".

In this situation, it may also be argued that the employer is at a disadvantage, because the employer is not supposed to ask an applicant if he or she would be available to work on all the days that the business is open (availability for weekend work); but, on the other hand, an applicant can collect all public information about the employer's activities, including when the employer is open for business. In other words, the full context of the applicant is not available or accessible to the employer, unlike the full context of the job as provided to the applicant by the organization in various forms (websites, company annual reports, etc.) relevant to the person-organization match model of selection. Therefore, the complete set of the applicant's motivations and skills in the person/job match model is not available to the employer to determine if indeed there is a match between the job requirements and the applicant's skills and motivations.

An employer is required, under US law that seeks to prevent the employment of illegal aliens, to ask for documentation about eligibility to work in the US only after the job has been offered. "To avoid the appearance of discrimination on the basis of national origin, it is a good idea to make the job offer contingent on proof of employment eligibility." (Phillips and Gully, 2012, p.59) The purpose of this law is to prevent illegal discrimination based on citizenship or national origin, but it puts the employer in a position of incurring talent acquisition costs without proof of the individual's eligibility to work. The question that arises is, "why should employers incur these costs only to face a situation where they may have to start the talent acquisition process all over again?" It may be argued that this situation puts the employer at an information disadvantage since the employer cannot determine whether the candidate has the qualifications to meet the job's requirements prior to offering the job.

\section{THE CONTEXT OF THE CONTRACT FORMATION}

A legal contract would require an offer to be made by one party and accepted by the other party with the attendant consideration. In the employment situation, the offer is usually made by the employer and the offer is accepted by a future employee of the employer with or without negotiations. 
In practice, the employer's offer is made by an employer's agent, who usually has full authority to make the offer. What can one say about the status of the applicant in the contract formation process? Is the applicant the principal representing herself or himself or is she or he an agent of some other entity, such as a family or a partner?

So we have two parties trying to form a contract. On the one hand, we have the employer's representative with full authority to make an offer with the attendant consideration (rewards or incentives to make the offer acceptable). On the other hand, we have an applicant who may be representing himself/herself as a single person or as a member of a family unit and needs to get the approval of that unit. In the latter situation, the applicant may not have full authority to enter into a contract. Therefore, it would appear that we may have two parties at the contract formation table with unequal powers.

Would it not be appropriate to have both partners with equal powers negotiate for their side? Suppose an applicant is married and needs to check with the spouse whether it is acceptable to accept a job offer, for example, at another location. If the spouse is the final authority in this situation, why should the employer not have the spouse as part of the contract formation process? The law, however, does not allow employers to ask about marital status in the data collection phase to determine suitability for employment. In other words, the employer has no access to the real decision-maker and the real decision-maker is not part of the formal process of being actively involved with the employer in the decision-making. The employer may therefore be considered to be at a disadvantage because the employer is not allowed to deal with the principal; the employer only deals with the agent who may not have full authority to negotiate for the principal.

It may therefore be argued that regulations which were meant to make it more difficult for employers to engage in illegal or unfair discrimination in the employment process have put the employer at an information disadvantage in terms of determining the suitability of a candidate for employment.

Consider the following actual experience of a university trying to fill a faculty position by a qualified candidate. There was an offer by the university, an acceptance of the offer by the applicant, and arrangements were being made for office space for the new member of the faculty. Three weeks later, the university received a letter from the said applicant withdrawing the acceptance of the offer because the spouse would not relocate. In this situation, if the university had withdrawn the offer, the applicant would have been in a position to file a promissory estoppel case against the university. ${ }^{2}$ On the other hand, is it practicable for the university to file a similar lawsuit against the applicant? In this case, the university could not legally collect any data on the spouse (the real decisionmaker) to assess the suitability of the candidate. Does this make for equal partners in the contract formation process? These questions will not arise in countries where it is legal to ask information about marital status or religion, or not illegal to ask for such information.

\section{CORRECTING THE INEQUALITIES}

Some relevant questions that may be raised are: 1) do we need to correct these perceived inequalities? and 2) can we correct the situation without creating other operational problems? In effect, will trying to correct these perceived inequalities lead to reducing the equal employment opportunities for all applicants for employment? These questions may need to be addressed. In the meantime, we propose some ways of addressing the inequality issues raised in this paper.

The first approach we propose is to use the existing practice of trying to obtain required information without breaking the law. For example, employers are not allowed to ask about age but may ask if the applicant has reached the age of majority (Gomez-Mejia, Balkin, and Cardy, 2010, p.113.). Similarly, employers may not ask

\footnotetext{
${ }^{2}$ Simply put, promissory estoppels have four necessary elements which the plaintiff must prove:

- there was a promise

- that was reasonably relied upon

- resulting legal detriment to the promise

- justice requires enforcement of the promise
} 
about citizenship unless it is a bona fide occupational qualification (BFOQ), but they may ask if the applicant has the legal right to work. Even in this situation, the employer may not ask for verifying documents until the individual has been hired (Heneman, Judge, and Kammeyer-Mueller, 2012, p.74). Using similar logic, employers ought to be able to ask an applicant if he or she is indeed the final decision-maker if an offer of employment is made. This information will hopefully put the employer in a position where the parties in the contract formation process have equal power to engage in a contract formation activity, as the "at will doctrine" would suggest, or at least let the employer know, that the other side is being represented by an agent who may not have full authority to engage in the consummation of an agreement.

It may be argued that information required as a BFOQ on assumption of duty; for example, the legal right to work, should be considered as a BFOQ at the beginning of the selection process. In the case of disability, the law requires that only those who can show that they can perform the essential functions of the job are indeed qualified. Employers are not expected to hire a person with disabilities and then require the employee to show the ability to perform the essential function. Being able to perform the essential functions is considered a BFOQ. Using this type of logic, we propose that all job-related factors should be considered BFOQs; e.g., age is a BFOQ for some jobs (commercial pilots). So, if we can ask for the age of a pilot prior to hiring and ask a disabled person to show their ability to perform the essential functions of a job with or without reasonable accommodation, why should a prospective employee not show that he or she has the legal right to work?

\section{CONCLUSION}

It is our hope that this paper generates a discussion of all consequences of EEO regulations. Such discussions should provoke revisiting some of the regulations in such a way that as employers comply with the regulations, they are not put at a disadvantage. The process of acquiring new talent does require organizations to incur a number of expenses which cost a lot more than zero dollars. It will be beneficial to organizations if they can be more certain as to who is on the other side as they try to form an employment relationship.

\section{AUTHOR INFORMATION}

John N. Orife is an Associate Professor and former Chairperson in the Department of Management, Indiana University of Pennsylvania, where he teaches graduate and undergraduate courses in human resource management, organization theory, and strategic management. Previously, he was Director of Training at the Nigerian Centre for Management Development where he consulted on several World Bank and Commonwealth Secretariat projects. He was the founding Editor, Nigerian Management Review. He received the Ph.D. and M.B.A. degrees from Michigan State University and the B.Sc. from the University of Nigeria. Dr. Orife also teaches graduate courses for Central Michigan University's week-end programs. E-mail: jorife@iup.edu (Corresponding author)

Maali H. Ashamalla is a Professor of Management at Indiana University of Pennsylvania and has taught graduate and undergraduate courses in several universities in the United States and overseas for over 25 years. She is a Senior Fulbright Scholar. She has published sixteen journal articles, five book chapters, and over forty-eight conference papers, including best paper awards. She has obtained ten Government and University research grants. She has received teaching excellence and outstanding service awards from the College and the University at large. She has conducted very intensive international consultancy projects in over thirty countries, and has traveled to over forty countries. E-mail: ashamala@iup.edu

Frederick J. Slack is an Associate Professor in the Department of Management, Indiana University of Pennsylvania, where he teaches graduate and undergraduate courses in human resource management, organization theory, and strategic management. He received the Ph.D. and M.B.A. degrees from the University of Pittsburgh. E-mail: fslack@iup.edu

\section{REFERENCES}

1. Basim, H.N., Sesen, H. and Sesen, E. (2007). Are they equal? Comparison of Turkish and English Job Announcements in terms of Some Discrimination Factors. Humanity \& Social Sciences Journal, 2 (1). 
2. Gatewood, R.D., Field, H.S. and Barrick, M. (2008). Human Resource Selection. Mason, OH: ThompsonSouthwestern.

3. Gomez-Mejia, L.R., Balkin, D.B. and Cardy, R.L. (2010 and 2001). Managing Human Resources. Boston, Prentice Hall.

4. Heneman, H.G., Judge, T.A. \& Kammeyer-Mueller, J.D. (2012). Staffing Organizations. Middleton, WI, McGraw-Hill Irwin.

5. Minton-Eversole, T. (2009). Overseas assignments keep pace but economic conditions the reins. Special Supplement to HRMagazine SHRM's 2009 HR Trend Book.

6. Pace, A. (2009). Training for the leap overseas. Training \& Development, 63, August.

7. Phillips, J.M. and Gully, S.M. (2012). Strategic Staffing. Boston, Prentice Hall.

8. Rynes, S. And Barber, A.E. (1990). Applicant attraction strategies: An organizational perspective. Academy of Management Review, 15, 286-310.

9. Sesen, E. (2006). Equal employment opportunities in the adaptation process of Turkey to EU. Paper presented at the ECPR $3{ }^{\text {rd }}$ Pan-European Conference, Bilgi University, Istanbul, September 22. 